\title{
SEXUAL DIMORPHISM IN DISTRIBUTION OF HAIR ON THE PHALANGES OF HAND OF UNDERGRADUATE MEDICAL STUDENTS OF NEPALGUNJ MEDICAL COLLEGE, NEPAL
}

\author{
Laxmi Bhattarai, ${ }^{1}$ Bishnu Gautam, ${ }^{2}$ Niraj Pandey, ${ }^{1}$ Sudikshya $\mathrm{KC}^{3}$
}

\section{ABSTRACT}

\section{INTRODUCTION}

This study was conducted to evaluate different hair patterns on the dorsal aspect of phalanges of both hands and compare it between males and females.

\section{MATERIAL AND METHODS}

The present study was carried out in 300 undergraduate medical students (males and females 150 each) of Nepalgunj Medical College, Nepalgunj, Nepal. Distribution of phalangeal hair was observed by using hand lens under adequate light. Data was collected on proximal, middle and distal phalanges according to modified scheme of Burnstein classification.

\section{RESULTS}

Statistical analysis showed that there was significant difference $(p=0.000)$ in the average value of different patterns in distribution of hair on proximal phalanges of both hands. The most common pattern between both sexes is 1-2-3-4-5 (67\%) but frequency is slightly less in females (56\%) as compared to males (78\%). In case of middle phalanges, result showed that there is significant difference $(\mathrm{p}=0.665)$ in the average value. The most common pattern between both the sexes is 3-45 (23\%). Result also revealed that hair on middle phalanges is absent in $53.33 \%$ female and $35.33 \%$ males.

\section{CONCLUSION}

This study was carried out using standard anthropometric method. Hence, this result is useful because of their anthropological significance and is recommended to forensic experts in deciding sex, nationalism and race.

KEYWORDS Distribution of hair, proximal and middle phalanges, hair patterns

1. Department of Anatomy, Universal College of Medical Sciences, Bhairahawa, Nepal

2. Department of Obstetrics \& Gynecology, Lumbini Zonal Hospital, Butwal, Nepal

3. Department of Anatomy, Lumbini Medical College, Palpa, Nepal

DOI: https://doi.org/10.3126/jucms.v6i2.22476

\author{
For correspondence \\ Dr. Laxmi Bhattarai \\ Department of Anatomy \\ Universal College of Medical Sciences \\ Bhairahawa, Nepal \\ Email: gautambriana6876@gmail.com
}




\section{INTRODUCTION}

Sexual dimorphism is common in human. Significant differences between males and females exist in many aspects. Within human population, age and sex differences in texture and distribution of hair are well recognized. ${ }^{1}$ A specific hair distribution which has attracted attention is the phalangeal hair patterns of hand. In this study, sexual dimorphism in the distribution of hair on the phalanges of both hands are analyzed.

Hair is filamentous keratinized structure. It is epidermal derivative of the skin, which acts as protective function against mechanical injury and assists in thermoregulation in mammals. ${ }^{2}$ In human, hairs are concentrated on some areas of body for example head, pubic, axilla, eyelashes and eyebrows while they are absent from few areas including thick skin of palm, soles, flexor surface of digits and certain other regions such as umbilicus, nipples, glans penis, clitoris and labia minor.

Hairs are commonly present on the basal segments of the digits and invariably absent on the terminal digits. Distribution of hair on the phalanges of hand has been of special interest from evolutionary standpoint since time in memorial. ${ }^{4}$ Hair distribution on the dorsum of phalanges of both hands shows a wide variation in relation to race, nationality and ethnic group. So, it is of medicolegal and anthropological importance.

\section{MATERIAL AND METHODS}

The present study is a descriptive cross-sectional study (convenient method). For this study, 300 students (males $=150$ and females $=150$ ) of age group between 18-25 years were taken. Ethical clearance was taken from ethical and subject research committee of Nepalgunj Medical College, Nepalgunj, Nepal. Students were explained about the procedure and written informed consent was taken from each students. The study was carried out for the presence and absence of hair on the dorsal aspect of phalanges of each digit on both hands by close inspection of clean and dry hands under adequate light against dark background with magnifying lens. In some cases where hair was not seen, pits of hair follicles were recorded as the presence of hair. The collected data were grouped under various hair patterns on proximal and middle phalanges of both hands. Students with any hand deformity such as permanent scars due to trauma, congenital hand defects and chronic skin disease of hand were not included in the study. The data so collected was tabulated in various groups according to Burnstein ${ }^{5}$ (1949) classification as detailed below: The data was collected, tabulated and statistically analyzed using SPSS version 20 (Statistical
Package for Social Sciences). For obtaining p-value, chisquare test was applied in this study

1) Hair present in digit 1 (thumb)

2) Hair present in digit 2 (index finger)

3) Hair present in digit 3 (middle finger)

4) Hair present in digit 4 (ring finger)

5) Hair present in digit 5 (little finger)

Table 1. Hair patterns on proximal and middle phalanges of both hands

\begin{tabular}{|c|l|}
\hline Patterns on proximal phalanges & Patterns on middle phalanges \\
\hline 1. Hair on 1-2-3-4-5 digits & 1. Hair on 2-3-4-5 digits \\
\hline 2. Hair on 2-3-4-5 digits & 2. Hair on 3-4-5 digits \\
\hline 3. Hair on 3-4-5 digits & 3. Hair on 3-4 digits \\
\hline 4. Hair on 2-3-4 digits & 4. Hair on 3rd digits \\
\hline 5. Hair on 4-5 digits & 5. Hair on 4th digits \\
\hline 6. Hair on 4th digits & 6. Hair on 5th digits \\
\hline & 7. Absent \\
\hline
\end{tabular}

\section{RESULTS}

This analysis includes 300 (150 males and 150 females) undergraduate medical students.

Table 2. Shows different patterns in distribution of hair on the proximal phalanges of both hands and their total percentage among males and females

\begin{tabular}{|llll|}
\hline Patterns & \multicolumn{2}{c}{ Sex } & Total \\
& Males & Females & \\
\hline $1-2-3-4-5$ & $117(78 \%)$ & $84(56 \%)$ & $201(67 \%)$ \\
\hline $2-3-4-5$ & $33(22 \%)$ & $41(27.33 \%)$ & $74(24.66 \%)$ \\
\hline $3-4-5$ & 0 & $10(6.66 \%)$ & $10(3.33 \%)$ \\
\hline 4 & 0 & $4(2.66 \%)$ & $4(1.33 \%)$ \\
\hline $2-3-4$ & 0 & $1(0.66 \%)$ & $1(0.33 \%)$ \\
\hline $4-5$ & 0 & $10(6.66 \%)$ & $10(3.33 \%)$ \\
\hline t-value & 5.398 & & \\
\hline p-value & 0.001 & & \\
\hline
\end{tabular}

Table 3. Shows different patterns in distribution of hair on the middle phalanges of both hands and their total percentage among male and female

\begin{tabular}{|llll|}
\hline \multicolumn{1}{|c}{ Patterns } & \multicolumn{2}{c}{ Sex } & Total \\
& Males & Females & \\
\hline $2-3-4-5$ & $11(7.33 \%)$ & 0 & $11(3.66 \%)$ \\
\hline $3-4-5$ & $37(24.66 \%)$ & $32(21.33 \%)$ & $69(23 \%)$ \\
\hline $3-4$ & $23(15.33 \%)$ & $21(14 \%)$ & $44(14.66 \%)$ \\
\hline 3 & $9(6 \%)$ & $1(0.66 \%)$ & $10(3.33 \%)$ \\
\hline 4 & $16(10.66 \%)$ & $10(0.66 \%)$ & $26(8.66 \%)$ \\
\hline 5 & $1(0.66 \%)$ & $6(4 \%)$ & $7(2.33 \%)$ \\
\hline Absent & $53(35.33 \%)$ & $80(53.33 \%)$ & $133(44.33 \%)$ \\
\hline t-value & 5.398 & & \\
\hline p-value & 0.665 & & \\
\hline
\end{tabular}


It is clear from the above tables (Tables 1,2 and 3) that there is statistically significant difference $(p<0.001)$ in the average value of different patterns in distribution of hair on proximal phalanges and insignificant difference $(p<0.665)$ in the average value of different patterns on distribution of hair on middle phalanges of both hands.

Table 2 reveals that hair pattern 1-2-3-4-5 is present in $78 \%$ of total males where as in females the frequency is less $(56 \%)$ as compared to males. Similarly, patterns 3-4-5, 4, 2-3-4, 4-5 are absent in case of males whereas present in females. Table 3 shows hair on middle phalanges is absent in $44 \%$ of total males and females out of which $35.33 \%$ is males and $53.33 \%$ is females. Likewise, pattern $2-3-4-5$ is absent in case of females.

\section{DISCUSSION}

The purpose of this study was to observe the distribution of hair patterns on the proximal and middle phalanges of both hands and to correlate the relationship between various patterns between males and females. The study conducted by Dharap et $\mathrm{al}^{6}$ among Chinese population in Malaysia reported significantly lower difference $(p<0.05)$ in distribution of hair on the proximal phalanges of hand between males and females whereas among Kanuris study showed insignificant sex difference. On the other hand, Babu et $\mathrm{al}^{7}$ revealed in his study that there was insignificant difference in all the patterns except on pattern 3-4 on middle phalanges of both hands that showed significant difference $(p<0.005)$ between males and females. Onyije and Oyinbo ${ }^{8}$ stated in their result that pattern 3-4-5 on middle phalanges of both hands showed significant difference between males and females. Aboagye et $\mathrm{al}^{9}$ found statistically insignificant difference $(p<0.2533)$ in the average values of different patterns on distribution of hair on middle phalanges of hand.

In the present study, the pattern $1-2-3-4-5$ on proximal phalanges of both hands is more in males (78\%) than that of females $(56 \%)$. However Ordu ${ }^{10}$ among Ibubios of South Nigeria reported higher frequency of hair pattern distribution in females than in males. The pattern 3-4-5 was absent in males in this study which was not reported by other studies. Most of the studies observed low incidence in distribution of pattern 2-3-4 on proximal phalanges of hand but Ordu ${ }^{10}$ observed higher incidence in both males (36\%) and females $(20 \%)$ whereas this study showed very low incidence in case of females $(0.66 \%)$ and absent in males. It is interesting to note that the study done by Hatiboglu ${ }^{11}$ observed absence of such pattern in both males and females.

In this study, the pattern 4-5 in proximal phalanges of both hands was absent in males whereas it was present in females
$(6.66 \%)$ which is in accordance with the study of Olabiye et $\mathrm{al}^{12}$ and Babu et $\mathrm{al}^{7}$ but Aboagye et $\mathrm{al}^{9}$ found such pattern in both males and females. Pattern 2-3-4-5 on the middle phalanges of both hands was present in males whereas absent in females which was in contradiction to the study conducted by Hatiboglu ${ }^{11}$ and Aboagye et $\mathrm{al}^{9}$. However, most of the earlier workers ${ }^{3,7,9,13}$ observed such pattern both in males and females. Patterns 3-4-5 and 3-4 are slightly higher in males than in females which is in resemblance with the observation of Hatiboglu ${ }^{11}$, Olabiye et $\mathrm{al}^{11}$ and Babu et al. ${ }^{7}$ Hair on $4^{\text {th }}$ and $5^{\text {th }}$ digits of middle phalanges was present in both the sexes but Babu et $\mathrm{al}^{7}$ did not report such patterns. Bhasin ${ }^{14}$ reported high frequency of absence of hair on middle phalanges in Nepalese population among Newar community. Present study showed $35.33 \%$ and $53.33 \%$ absence of hair on middle phalanges in males and females respectively. Among the Gorkhas of Dhauladhar range, Parmer $^{15}$ observed that $60 \%$ male population did not have hair in middle phalanges.

\section{CONCLUSION}

Distribution of hair on the phalanges of hand is one of the most important aspects in accessing sexual dimorphism. Several authors have described various patterns on distribution of hair on the phalanges of hands and compared different patterns between males and females. The purpose of this study was to analyze the presence of sexual dimorphism in different patterns on distribution of hair on the phalanges of hand. This study was carried out using standard anthropometric method. Hence, this result is useful because of their anthropological significance and is recommended to forensic experts in deciding race, nationalism and the sex. Thus, study on distribution of hair on the phalanges of hand has a medicolegal importance.

\section{REFERENCES}

1. Standring S, Borley NR, Healy JC, Collins P, Johnson D, Crossman AR et al, editors. Grays Anatomy, The anatomical basics of clinical practice. $40^{\text {th }}$ ed. Spain: Elsevier Churchill Livingstone; 2008. P. 160

2. Elbastawisy YM. Distribution of dorsal phalangeal hair of hands in Natives of Almadinah. JAm Sci 2013;9(11):17-21.

3. Oyerinde OO, Olaitan OL. Phalangeal hair distribution among field and office workers in western part of Nigeria implications for health and safety of workers. J Social Edu Afri 2009;8(1):116.

4. Danforth CH. Distribution of hair on the digits in man. Am J Physiol Anthrop 1921;4:189-204.

5. Bernstein. The middigital hair genes. J Hered 1949;40:127-31. 
6. Dharap AS, Lim BC, Ong LB. Distribution of hair on the dorsum of the phalanges of the hand in Chinese population from Malaysia. Anthropol 1996;54(4):311-16.

7. Babu RS, Kumar DA, Sujatha. Dorsal distribution of hair on the phalanges of hand in Sub-Urban area of Hyderabad. Int J Pharm Bio Sci 2013;4(3):562-67.

8. Onyije FM, Oyinbo CA. Hair distribution on the phalanges of hand in Ogba tribe River State. Asian J Biol Sci 2011;4(3):27781

9. Aboagye B, Tsegah KM, Ussif AM. Distribution of Hairs on the Phalanges of Hands among Ghanaians. 2013, Jul 3 (cited 2014 Aug 15); (3 Screens) Available from:URL:http://dx/dog.org/ $10.1155 / 2013 / 386819$.

10. Ordu KS. Interphalangeal hair distribution on the hands and feet in relation to age, job type and gender amongst the Effiks and Ibibos of South Nigeria. Curr Res J of Biol Sci 2013;5(3):10914.

11. Hatiboglu MT. The hair distribution on the phalanges of hand among Truks. J Anatomy 1983;137(3):537-40.

12. Olabiyi AO, Akpantah AO, Oyerinde OF, Gbotolorun SC, Eluwa MA, Ekanem TB. The distribution of hair on the phalanges of a sample population of Nigerian Yorubas in relation to sex, age and job type. Niger J Physiol Sci 2008;23(1-2):101-4.

13. Ali S, Sharma N, Mandlio RS, Usmani D. Study of distribution of hair on phalanges of hand in North India. Innov J Med Health Sci 2012;3(1):26-28

14. Bhasin MK. A study of distribution of mid-digital hair among Newars of Nepal. Acta Genet Med Gem (Roma) 1967;16:199213.

15. Parmer P. The distribution of the middle phalangeal hair among the Indian population. J Royal Anthropol 1965;95:115-26. 